\title{
The activin receptor-like kinase 6 Booroola mutation enhances suppressive effects of bone morphogenetic protein 2 (BMP2), BMP4, BMP6 and growth and differentiation factor-9 on FSH release from ovine primary pituitary cell cultures
}

\author{
Julia M Young ${ }^{1,5}$, Jennifer L Juengel ${ }^{2}$, Kenneth G Dodds ${ }^{3}$, Mhairi Laird ${ }^{6}$, Peter K Dearden ${ }^{5}$, \\ Alan S McNeilly ${ }^{6}$, Kenneth P McNatty ${ }^{4}$ and Theresa Wilson ${ }^{1}$ \\ ${ }^{1}$ AgResearch Molecular Biology Unit, Department of Biochemistry, University of Otago, PO Box 56, Dunedin, New Zealand \\ ${ }^{2}$ AgResearch, Wallaceville Animal Research Centre, Upper Hutt, New Zealand \\ ${ }^{3}$ AgResearch Invermay Agricultural Centre, Mosgiel, New Zealand \\ ${ }^{4}$ School of Biological Sciences, Victoria University of Wellington, Wellington, New Zealand \\ ${ }^{5}$ Laboratory for Development and Evolution, Biochemistry Department, University of Otago, PO Box 56, Dunedin, New Zealand \\ ${ }^{6}$ Medical Research Council, Human Reproductive Sciences Unit, Centre for Reproductive Biology, The University of Edinburgh Chancellor's Building, 49 Little \\ France Crescent, Old Dalkeith Road, Edinburgh EH16 4SB, UK \\ (Correspondence should be addressed to J M Young; Email: julia.young@agresearch.co.nz)
}

\begin{abstract}
Bone morphogenetic proteins (BMPs) have been shown to influence the regulation of FSH synthesis and secretion at the level of the pituitary. Primary pituitary cells were harvested and cultured from Booroola ewes homozygous for a mutation in activin receptor-like kinase 6 (ALK6) also known as BMP receptor IB (BMPRIB), and from wild-type (WT) ewes to determine if the mutation caused alterations in FSH secretion in vitro. The cells were collected $24 \mathrm{~h}$ following induction of luteolysis and cultured for $72 \mathrm{~h}$ prior to being challenged for $24 \mathrm{~h}$ with BMP2, BMP4, BMP6, growth and differentiation factor-9 (GDF9), transforming growth factor- $\beta 1$, activin- $A$ and GnRH. The levels of FSH and LH were measured by RIA and then compared with the untreated controls. Primary
\end{abstract}

pituitary cell cultures from Booroola ewes secreted less FSH than WT cells in the presence of BMP2, BMP4 and BMP6. These BMPs did not affect the FSH stores within the cells, or the levels of LH released. GDF9 appeared to act in a BMPlike manner by suppressing FSH secretion. The ALK6 receptor however, was not found to co-localise with gonadotroph cells in either Booroola or WT pituitary tissues. These findings imply that the increased sensitivity of Booroola cells to BMP2, BMP4, BMP6 and GDF9 cannot be due to the direct action of the ALK6 mutant Booroola receptor in the cells that synthesise FSH.

Journal of Endocrinology (2008) 196, 251-261

\section{Introduction}

Bone morphogenetic proteins (BMP) have emerged as important regulators of ovarian physiology and fertility. There have been a number of sheep breeds with altered fecundity that have been identified with genetic mutations in BMP15 and growth and differentiation factor-9 (GDF9) and the related receptor activin receptor-like kinase 6 (ALK6; BMP receptor type IB, BMPRIB; McNatty et al. 2005). Studies have revealed that the high prolificacy identified in Booroola ewes is the result of a mutation in the gene encoding ALK6 also known as BMPRIB (Mulsant et al. 2001, Souza et al. 2001, Wilson et al. 2001). The ALK6 mutation (Q249R) is located in the highly conserved intracellular kinase signalling domain of the receptor. The identification of ALK6 and the related BMP15 and GDF9 mutations in prolific sheep suggests a pivotal role of ligands of the transforming growth factor- $\beta$ (TGF $\beta$ ) superfamily in the regulation and control of follicular growth as well as of ovulation rate. The growth factors BMP6, BMP15 and GDF9 are produced by the oocyte (McNatty et al. 2005), whereas the types IA, type IB and type II BMP receptors are present in both oocytes and somatic cells of ovarian follicles (Souza et al. 2002) as well as in the pituitary gland of sheep (Faure et al. 2005). Of those sheep lines with high fecundity, the ALK6 mutation in Booroola sheep causes one of the largest positive effects on ovulation rate (Davis 2004).

Follicle-stimulating hormone (FSH) is an essential factor in the regulation of follicular development. Booroola sheep have been studied widely investigating the concentrations of FSH in plasma in different flocks across the globe. Two key studies revealed that New Zealand-derived homozygous mutant 
Booroola Merinos have higher plasma FSH concentrations than WT ewes with the plasma concentrations in heterozygous mutants being intermediate. The first study determined concentrations of FSH and luteinising hormone (LH) in ovary-intact ewes (McNatty et al. 1987), followed by a subsequent comparison in ovariectomised homozygous Booroola (BB) and non-carrier ewes (McNatty et al. 1989). In these flocks, the evidence was that the fecundity gene $(\mathrm{FecB})$ influenced the plasma concentrations of FSH (McNatty et al. 1991a, 1992, Montgomery et al. 1992). The plasma concentrations of FSH were found to be consistently higher in the homozygous Booroola ewes compared with the wild-type (WT) ewes throughout the oestrous cycle, anoestrus and after ovariectomy. They were also found to be higher in ovariectomised or ovary-intact ewes treated with gonadotrophin-releasing hormone $(\mathrm{GnRH})$ following hypothalamic-pituitary disconnection (HPD; McNatty et al. 1987, 1989, 1991a, 1993). When HPD or Deslorelin-treated (GnRH agonist) homozygous ALK6 (BB) and WT ewes were administered identical doses of FSH, the ovulation rate and plasma concentrations of FSH in those animals which ovulated was the same in both genotypes (Hudson et al. 1999). They demonstrated that in both BB and WT ewes, higher ovulation rates were observed as the FSH dose increased. This suggested that the higher mean ovulation rate in $\mathrm{BB}$ ewes compared with the WT genotype was due to effects of the $F e c B$ gene acting on both the ovarian follicles and on the secretion of FSH from the pituitary gland. However, the increased concentrations of circulating FSH observed in New Zealand flocks have not been observed in Booroola flocks in other parts of the world (Driancourt et al. 1991, Souza et al. 1997). Since the Booroolas in the New Zealand studies were often selected on the basis of exceptionally high ovulation rates (e.g. $\geq 7$ ), the possibility arises that these animals had another 'gene' influencing ovulation rate in addition to the ALK6 mutation.

Certain members of the TGF $\beta$ superfamily are known to regulate FSH production, with activins being the potent stimulators of FSH secretion (Carroll et al. 1991a,b, Weiss et al. 1992, 1995). Presently, many of the BMPs are now being implicated in modulating FSH levels. For example, BMP6 and BMP7 stimulate FSH $\beta$ expression in rodent pituitary cells (Huang et al. 2001) and a selective and specific role of BMP15 in regulating FSH production was reported in L $\beta$ T2 cells (Otsuka \& Shimasaki 2002). In addition, BMP4 has been shown to inhibit FSH secretion from sheep pituitary cultures (Faure et al. 2005). Taken together, these studies demonstrate that a functional BMP system is present in the pituitary gland. However, it is not clear whether the ALK6 mutation in Booroola sheep affects the level of BMP ligand action on pituitary FSH secretion directly or indirectly.

As BMP2, BMP4, BMP6, BMP7 and GDF9, as well as BMPRIA and ALK6 (BMPRIB), and BMPRII mRNAs are found in sheep pituitary tissue (Faure et al. 2005; unpublished results), and gonadotrophs were shown to express BMPRII and BMPRIA, but not ALK6 (Faure et al.
2005), the possibility exists that the exposure of pituitary gonadotrophs to certain TGF $\beta$ family members may result in differing FSH concentrations between BB and WT ewes.

In the present study, we investigated whether isolated primary pituitary cell cultures from Booroola Merino ewes produce altered concentrations of FSH compared with cells from WT sheep when challenged with various TGF $\beta$ family ligands.

\section{Materials and Methods}

\section{Reagents}

The cell culture reagents used were Dulbecco's modified Eagle's medium (DMEM) and Hanks balanced salt solution (HBSS) from Invitrogen. Penicillin and streptomycin, MEM non-essential amino acids, trypsin, L-glutamine, fetal calf serum (FCS) and horse serum were also purchased from Invitrogen. Protease inhibitors were sourced from Roche Applied Science. Human recombinant activin-A, BMP2, BMP4, BMP6 and TGF $\beta 1$ were obtained from R \& D Systems through Pharmaco, Auckland, New Zealand. GnRH was purchased from Sigma-Aldrich New Zealand Ltd, and GDF-9 and its control medium were produced as described previously (McNatty et al. 2005). The prostaglandin F2- $\alpha$ analogue, Estrumate (active ingredient is Chloprostenol $250 \mu \mathrm{g} / \mathrm{ml}$ ) was sourced from SVS Veterinary Supplies, Christchurch, New Zealand.

\section{Animals}

The experimental procedures reported in this study were carried out after approval had been granted by the Animal Ethics Committee of the AgResearch Invermay Agricultural Research Centre. The genotypes compared were the highly prolific homozygous Booroola carrier ewe and the noncarrier with a low prolificacy. These animals (3-7 years of age) were from the AgResearch Invermay Booroola flock. The ewes had ovulation rates measured by laparoscopy during their lifetime to confirm the genotypic differences were observed phenotypically. For cell cultures, pituitary glands were recovered from ewes either homozygous for the Booroola gene $(n=19)$ or non-carrier $(n=20)$ ewes. The animals were weighed prior to killing. The pituitaries were recovered during the follicular phase of the oestrous cycle. Two doses of Estrumate, $0.6 \mathrm{ml}$, were administered intramuscularly 9 days apart. The pituitaries were recovered $\sim 24 \mathrm{~h}$ after the second treatment (follicular phase). Due to the large number of animals utilised in this study, the animals were killed in groups of two to three of each genotype over a period of 7 weeks during the months of May and June during the breeding season.

Pituitary tissues were harvested for immunohistochemical analyses during the following breeding season. Homozygous Booroola $(n=8)$ and WT $(n=8)$ ewes (aged 3-7 years) were 
administered with Estrumate in the same manner as described previously. To allow the collection of pituitaries in the mid-luteal and follicular phases of the oestrous cycle, pituitary glands were collected 10 days after the second treatment and at $36 \mathrm{~h}$ post a third treatment respectively. Oestrus was confirmed in ewes following the second injection of Estrumate using a vasectomised ram fitted with a marking harness.

\section{Pituitary cell cultures}

Pituitary glands were harvested from two to three animals of each genotype (BB or WT), each week for 7 weeks. The pituitary glands were placed in ice-cold HBSS supplemented with $1 \%$ FCS, penicillin (100 units/ml) and streptomycin $(100 \mu \mathrm{g} / \mathrm{ml})$. On returning to the laboratory, all extraneous material was removed under a dissection microscope and the gland itself weighed. The tissue was dissociated mechanically with a scalpel, placed in PBS supplemented with 1\% trypsin and incubated at $4{ }^{\circ} \mathrm{C}$ for $4 \mathrm{~h}$. The tissue was then placed in a $37^{\circ} \mathrm{C}$ shaking water bath for $20 \mathrm{~min}$, and the supernatant containing cells was removed. A further $4 \mathrm{ml}$ aliquot of PBS supplemented with $1 \%$ trypsin was added to the tissue and incubated again in the $37^{\circ} \mathrm{C}$ water bath. This was repeated four times (total of $80 \mathrm{~min}$ at $37^{\circ} \mathrm{C}$ ). Each cell supernatant was added to culture medium (DMEM supplemented with 5\% FCS, 5\% horse serum, penicillin 100 units $/ \mathrm{ml}$, streptomycin $100 \mu \mathrm{g} / \mathrm{ml}, 0 \cdot 03 \%$ L-glutamine and $1 \%$ essential amino acids) and centrifuged at $100 \boldsymbol{g}$ for $10 \mathrm{~min}$. The medium was removed, the cell pellet dispersed and thereafter pre-warmed culture medium added.

On completion of the enzymatic incubations, cells from each genotype were pooled (pituitary cells from two to three animals per pool), counted and plated in 48-well plates at $1 \times 10^{5}$ cells/well in $500 \mu \mathrm{l}$ culture media. The cells were allowed to attach for $72 \mathrm{~h}$ and the media was then removed and replaced with culture medium supplemented with test ligands at different concentrations (see Results). Each ligand concentration was replicated in eight different wells. After $24 \mathrm{~h}$, the media was removed and stored at $-20{ }^{\circ} \mathrm{C}$ for $\mathrm{FSH}$ and LH RIA. Additionally, the plates containing the cells were also frozen at $-20^{\circ} \mathrm{C}$ to assay for intracellular $\mathrm{FSH}$ content. The ligands tested included activin A, BMP2, BMP4, BMP6, TGF $\beta 1$ and GDF9. GnRH was included as a positive control. The test ligands were selected based on experiments previously carried out within our group showing their presence in ovine pituitary tissues. The three BMPs were known to activate the Smad $1 / 5 / 8$ pathway and TGF $\beta 1$, GDF9 and activin the Smad 2/3 pathway, were included to allow comparisons between ligands activating the different Smad pathways. The culture time of $24 \mathrm{~h}$ was chosen after preliminary cultures in our laboratory, and published results (Faure et al. 2005) indicated that effects of BMPs could be observed within $24 \mathrm{~h}$, albeit the effects were more pronounced at $72 \mathrm{~h}$ (Faure et al. 2005). The earlier time point was chosen to reduce the potential feedback mechanisms or influences of unknown cell-secreted factors in the culture environment.

FSH stored within cells was extracted by the addition of $100 \mu \mathrm{l}$ of $100 \mathrm{nM}$ sodium carbonate solution (containing $1 \times$ complete protease inhibitors, Roche) to each well. The plates were incubated at room temperature for $1 \mathrm{~h}$, and three cycles of rapid freeze-thaw were carried out. The lysates were centrifuged at $12000 \mathrm{~g}$ for $5 \mathrm{~min}$, and the supernatant collected and stored at $-20{ }^{\circ} \mathrm{C}$ for RIA. Two replicate wells for each treatment were lysed, and duplicate assays were carried out on each of the supernatants collected.

\section{Measurement of FSH and $\mathrm{LH}$}

The concentrations of LH and FSH were determined by RIA using reagents supplied by the National Hormone and Pituitary Programme (NIADDK, NIAMDD; Bethesda, MD, USA) as described previously (McLeod et al. 1997). The reference preparation and iodinated tracer for the LH RIA used highly purified ovine LH (CY1085 (biopotency of $3.45 \times$ NIH-LH-Sl)), and the FSH RIA reference preparation was USDA-oFSH-19-SIAFP-RP-2. In this study, the limit of sensitivity was calculated as two S.D. from the B0 (zero bound) upper limit of the standard curve (Chard 1995). The sensitivity of the FSH RIA was $0.49 \mathrm{ng} / \mathrm{ml}$ and the intra- and inter-assay coefficients of variance were calculated from the quality control samples to be $<15 \%$. The sensitivity of the LH RIA was $0.26 \mathrm{ng} / \mathrm{ml}$ and the intraand inter-assay coefficients of variation were $<15 \%$.

The mean \pm s.E.M. concentration of the secreted FSH in untreated BB cultures was $17 \cdot 5 \pm 1.9 \mathrm{ng} / \mathrm{ml}$ and this was not different to that observed in WT cultures $(14 \cdot 8 \pm 0 \cdot 8 \mathrm{ng} / \mathrm{ml})$. The mean \pm s.E.M. concentration of FSH present in cell lysates from untreated $\mathrm{BB}$ cells was $5 \cdot 0 \pm 0 \cdot 8 \mathrm{ng} / \mathrm{ml}$ of $\mathrm{FSH}$ produced from 100000 cells plated in each well at the start of the culture period, which was not significantly different from that in WT cells $(3 \cdot 8 \pm 0.4 \mathrm{ng} / \mathrm{ml})$. The mean \pm s.E.M. concentration of LH secreted from untreated cells was not different between genotypes $(64 \cdot 2 \pm 6 \cdot 6 \mathrm{ng} / \mathrm{ml}$ in $\mathrm{BB}$ and $60 \cdot 4 \pm 5 \cdot 4 \mathrm{ng} / \mathrm{ml}$ in WT). The concentrations of hormones overall from cultures were not significantly different between $\mathrm{BB}$ and WT genotypes.

\section{Immunohistochemistry}

Sheep pituitary glands were fixed in Bouins fluid $(750 \mathrm{ml}$ saturated picric acid solution, $250 \mathrm{ml}$ formaldehyde and $50 \mathrm{ml}$ glacial acetic acid) overnight and then rinsed in several changes of $70 \%$ ethanol for a period of not $<5$ days and not more than 10 days, before being dehydrated and embedded in paraffin wax. Sections (5 $\mu \mathrm{m}$ thick) were dewaxed in xylene and rehydrated in decreasing concentrations of alcohol (100, 90 and 75\%). Slides were washed twice for $5 \mathrm{~min}$ in PBS (Sigma-Aldrich) and then a combined avidin-biotin block was performed according to the manufacturer's instructions (Vector Laboratories, Peterborough, UK). 
For ALK6 detection, the sections were incubated at $4{ }^{\circ} \mathrm{C}$ overnight with polyclonal rabbit anti-ALK6 (kindly provided by Dr C Heldin, Ludwig Centre for Cancer Research, Uppsala) diluted 1:50 in PBS containing 20\% normal goat serum (Autogen bioclear LTD, Wiltshire, UK) and 5\% BSA (Roche; PBS/NGS/BSA). Negative controls were performed by replacing the first antibody with PBS/NGS/BSA. Sections were washed for 5 minutes twice in PBS, then the slides were incubated in goat anti-rabbit Alexa 488 (Molecular Probes, Eugene, OR, USA) diluted at 1:200 in PBS for $1 \mathrm{~h}$. After two 5-minute washes in PBS, the slides were blocked in $\mathrm{PBS} / \mathrm{NGS} / \mathrm{BSA}$ for $30 \mathrm{~min}$. Sections were then incubated at $4{ }^{\circ} \mathrm{C}$ overnight with either mouse monoclonal antibody directed against LH (1:2000; Dr J Roser, Univ. California, Davis) or FSH (1:75; Abcam, Cambridge, UK) diluted in PBS/NGS/BSA. Negative controls were performed by replacing the antibody with normal goat serum. After two washes in PBS, slides were incubated with goat anti-mouse Alexa 546 (Molecular Probes) diluted at 1:200 in PBS/NGS/BSA and washed again twice in PBS.

For BMPRII detection, the same procedure as just described was carried out with the addition of antigen retrieval procedures and alternate antibodies substituted where applicable. Antigen retrieval was performed by steaming the sections in a pressure cooker in citrate buffer $(0 \cdot 01 \mathrm{M}$; pH 6.0) for $5 \mathrm{~min}$ and then cooling for $20 \mathrm{~min}$. The first antibody utilised was rabbit anti-BMPRII (Dr C Heldin, Ludwig Centre for Cancer Research, Uppsala) diluted 1:50 in $\mathrm{PBS} / \mathrm{NGS} / \mathrm{BSA}$ and incubated $\mathrm{O} / \mathrm{N}$ at $4{ }^{\circ} \mathrm{C}$. This was detected by goat anti-rabbit Alexa (Molecular Probes) 488 diluted 1:200 in PBS for $1 \mathrm{~h}$. The second antibody was a mouse monoclonal directed against FSH (Abcam) diluted in PBS/NGS/BSA at 1:75. This was detected by goat antimouse Alexa (Molecular Probes) 546 at 1:200 in PBS for $1 \mathrm{~h}$.

All sections were counterstained for 2 min with TopRo Blue (Invitrogen) at 1:2000 for $2 \mathrm{~min}$. The slides were examined using LSM 510 Zeiss confocal microscope. Duplicate slides were analysed for each animal. In ALK6 incubations, the same animals were analysed for both FSH and $\mathrm{LH}$, four of each genotype at each phase of the oestrous cycle (total $n=8$ for each genotype). For BMPRII, one slide from the follicular phase was examined from four Booroola and four WT animals. ALK6 was examined more thoroughly across the cycle as the investigation was focused on the Booroola ALK6 mutation. Each slide contained two sections from which four fields were examined at random for each section.

\section{Statistical analysis}

Live weights of ewes and of wet tissue as well as ovulation rate data were each averaged and a S.D. calculated. A two-tailed $t$-test with unequal variances was performed to calculate levels of significance.
The RIA data were analysed using mixed model methods (using PROC MIXED of SAS), which make optimal use of differing amounts of replication at any level, using residual maximum likelihood (Patterson \& Thompson 1971). The levels were the duplicate assays from the same well, the wells containing repeats of the same ligand treatment and a combination of the pool of animals with the ligand at a particular concentration. These were fitted as nested random effects, i.e. duplicate was nested within well, and well was nested within animal pool-ligand concentration. In addition, the week of the experiment (equivalent to the pool of cells for each genotype) was fitted as an additional random effect. The fixed effects were the ligand (including controls), the concentration within each different ligand and the Booroola genotype effect, which was allowed to vary according to the ligand and its concentration (i.e. the genotype effect was fitted for each combination of ligand and concentration). Residual plots indicated that a log transformation was appropriate for these data. Random effects with zero variance components were dropped from the model, and the other components were re-estimated. Sub-hypotheses were tested by constructing appropriate contrasts. The estimated treatment means are plotted relative to their control (i.e. as percentage of control) along with bars indicating one S.E.M., i.e. the mean times the standard error of the ratio (SER). As the SERs are close to one (all are $<1 \cdot 11$ ), an $\sim 95 \%$ confidence interval for the treatment mean as a percentage of control is obtained as double this bar height extended above and below the estimated mean.

Immunohistochemistry data were analysed by totalling the number of cells stained across each analysis and calculating the proportion (and its S.E.M.) stained for each protein.

\section{Results}

Ovulation rates, live weights and wet pituitary weights of animals

To confirm the ewes were either high and low ovulating animals for each of the genotypes, laparoscopies were carried out over a 1 - to 5 -year period. The mean \pm s.E.M. ovulation rate of homozygous Booroola ewes was $5 \cdot 2 \pm 0 \cdot 2$, whereas that in WT ewes was $1.9 \pm 0 \cdot 1(P<0 \cdot 0001)$. Furthermore, each animal was confirmed as a homozygous carrier or noncarrier by the genetic marker test (Wilson et al. 2001).

The mean \pm S.E.M. weights for the pituitary glands from the homozygous carriers and non-carriers were $0.85 \mathrm{~g} \pm 0.05$ and $1.21 \mathrm{~g} \pm 0.09$ respectively; these means were significantly different $(P<0 \cdot 01)$. The mean live weights recorded for the homozygous carriers and non-carriers were $54 \cdot 2 \mathrm{~kg} \pm 1 \cdot 3$ and $58 \cdot 2 \mathrm{~kg} \pm 1 \cdot 0$ respectively $(P<0 \cdot 05)$.

\section{Effects of BMPs on pituitary cell gonadotrophin levels}

To investigate the influence of the ALK6 Booroola mutation, isolated pituitary cells were challenged with BMP2, BMP4 
and BMP6. The aim was to activate the post-receptor signal cascade specifically to test the effect of the ALK6 mutation on FSH secretion from gonadotroph cells. Treatment with GnRH was included as a positive control. As expected, $\mathrm{GnRH}(10,100$ and $1000 \mathrm{ng} / \mathrm{ml})$ stimulated FSH release when compared with untreated cells in both genotypes (Fig. 1). No genotype effects were observed when GnRH was present.

BMP2 consistently suppressed FSH release in cells from the homozygous carriers of the ALK6 mutation (BB) at all concentrations (29-31\%; $P<0.001$; Fig. 1). However, suppression was only observed in WT cells at $10 \mathrm{ng} / \mathrm{ml}$ BMP2 $(22 \% ; P<0 \cdot 01)$. The concentration of FSH in BB cell culture media was lower than in WT cell culture media at 100 and $1000 \mathrm{ng} / \mathrm{ml}(P<0 \cdot 05)$.

BMP4 consistently suppressed FSH release from BB cells (up to $38 \% ; P<0 \cdot 001$ ). The amount of FSH released from WT cells did not differ significantly from that in untreated cells, although it appeared that a slight suppression occurred (14\%). Genotype differences were observed between BB and WT cells at all concentrations of BMP4 tested (i.e. at $10 \mathrm{ng} / \mathrm{ml} P<0 \cdot 01,100$ and $1000 \mathrm{ng} / \mathrm{ml}$ both $P<0 \cdot 05)$.

BMP6 suppressed FSH release in BB cells by $22 \%$ at $10 \mathrm{ng} / \mathrm{ml}$ and $35 \%$ at $1000 \mathrm{ng} / \mathrm{ml}(P<0.01$ and $P<0.001$ respectively). Suppression was also observed in WT cells at $1000 \mathrm{ng} / \mathrm{ml}(24 \% ; P<0 \cdot 01)$. A significant difference between genotypes was noted at $10 \mathrm{ng} / \mathrm{ml} \mathrm{BMP6}(P<0 \cdot 05)$, but this was not consistently observed across all doses. There was a significant dose-dependent inhibitory trend in the pituitary cell release of FSH over the three concentrations of BMP6 in cell cultures from WT $(P<0 \cdot 01)$ and BB $(P<0 \cdot 05)$ animals.
The concentration of FSH stored within the cultured cells was also determined. There were no consistent trends in the intracellular levels of FSH either with respect to the genotype or the dose when pituitary cells were challenged with BMP ligands or GnRH (Fig. 2).

The amounts of LH secreted into the cell culture medium were significantly higher in the presence of GnRH (Fig. 3). LH secretion was higher at all concentrations of $\mathrm{GnRH}$ when compared with the untreated cells $(P<0.01$ for WT and $P<0.05$ for $\mathrm{BB})$. The response to $\mathrm{GnRH}$ increased by $20-25 \%$ over a tenfold increase in dose $(P<0 \cdot 05)$. There were no significant genotype differences amongst any of the treatments. None of the BMP ligands tested consistently altered LH secretion at any significant level. The only response reaching significance was $100 \mathrm{ng} / \mathrm{ml}$ BMP6 in BB cells.

\section{Effects of activin-A, GDF9 and TGF $\beta 1$ on pituitary cell secretion of gonadotrophins in vitro}

The effects of GDF9 and TGF $\beta 1$ on gonadotropin secretion from sheep pituitary cells in culture were measured in comparison with responses to activin-A, a known stimulator of FSH synthesis.

In the presence of activin-A, higher FSH output from both $\mathrm{BB} \quad(100 \mathrm{ng} / \mathrm{ml} ; \quad P<0 \cdot 05)$ and WT $(10-1000 \mathrm{ng} / \mathrm{ml}$; $P<0 \cdot 05)$ pituitary cells was observed (Fig. 4). The trend in the dose-dependent response from 1 to $100 \mathrm{ng} / \mathrm{ml}$ activin-A was highly significant in both the genotypes (both $P<0 \cdot 001$ ).

GDF9 treatment resulted in the suppression of FSH release from cells from BB animals at all concentrations $(10 \mathrm{ng} / \mathrm{ml}$, $P<0 \cdot 01 ; 100$ and $1000 \mathrm{ng} / \mathrm{ml}, \quad P<0 \cdot 05)$. However,

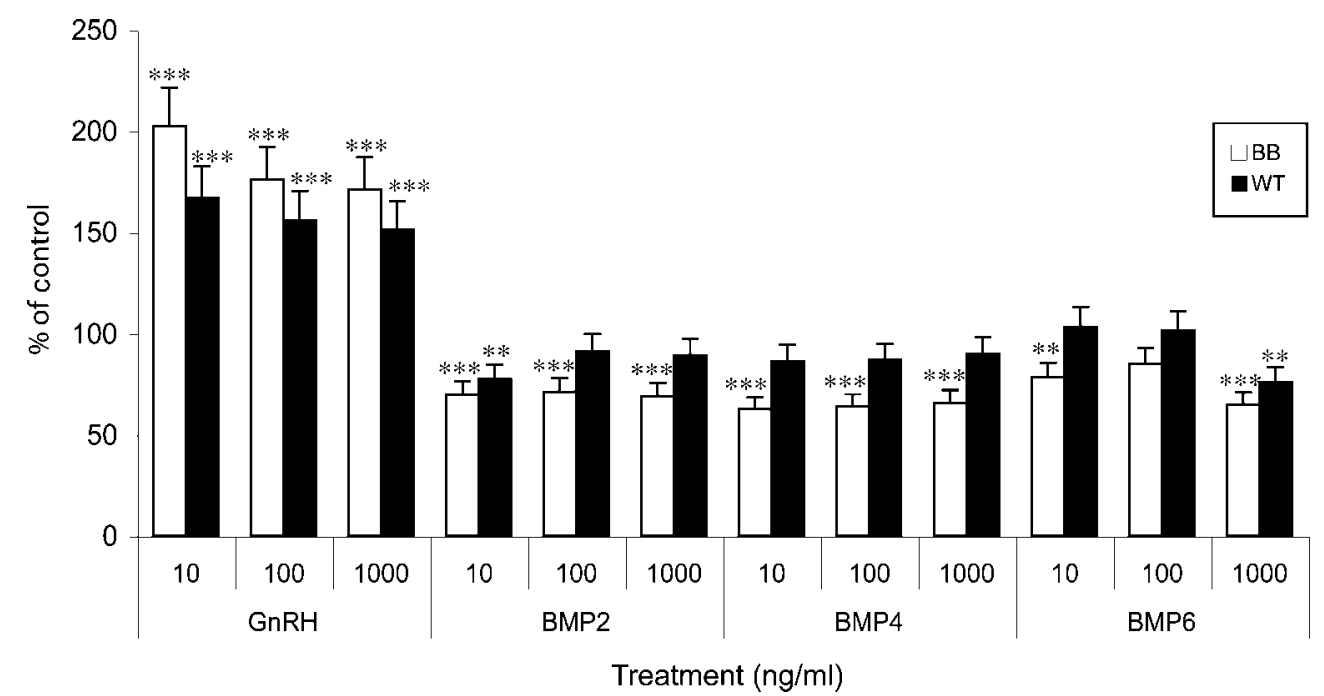

Figure 1 Dose-response of GnRH, BMP2, BMP4 and BMP6 on FSH release from ewe pituitary cells. Values are the analysed ratios of the treatment when compared with the control for each genotype. Standard errors of the ratio (SERs) over five to six pools of pituitary cells from each genotype range between $8 \cdot 8$ and $9 \cdot 9 \%$ for each treatment. The estimated mean times the SER are indicated by error bars. ${ }^{* *} P<0 \cdot 01,{ }^{* * *} P<0 \cdot 001$ compared with control. 


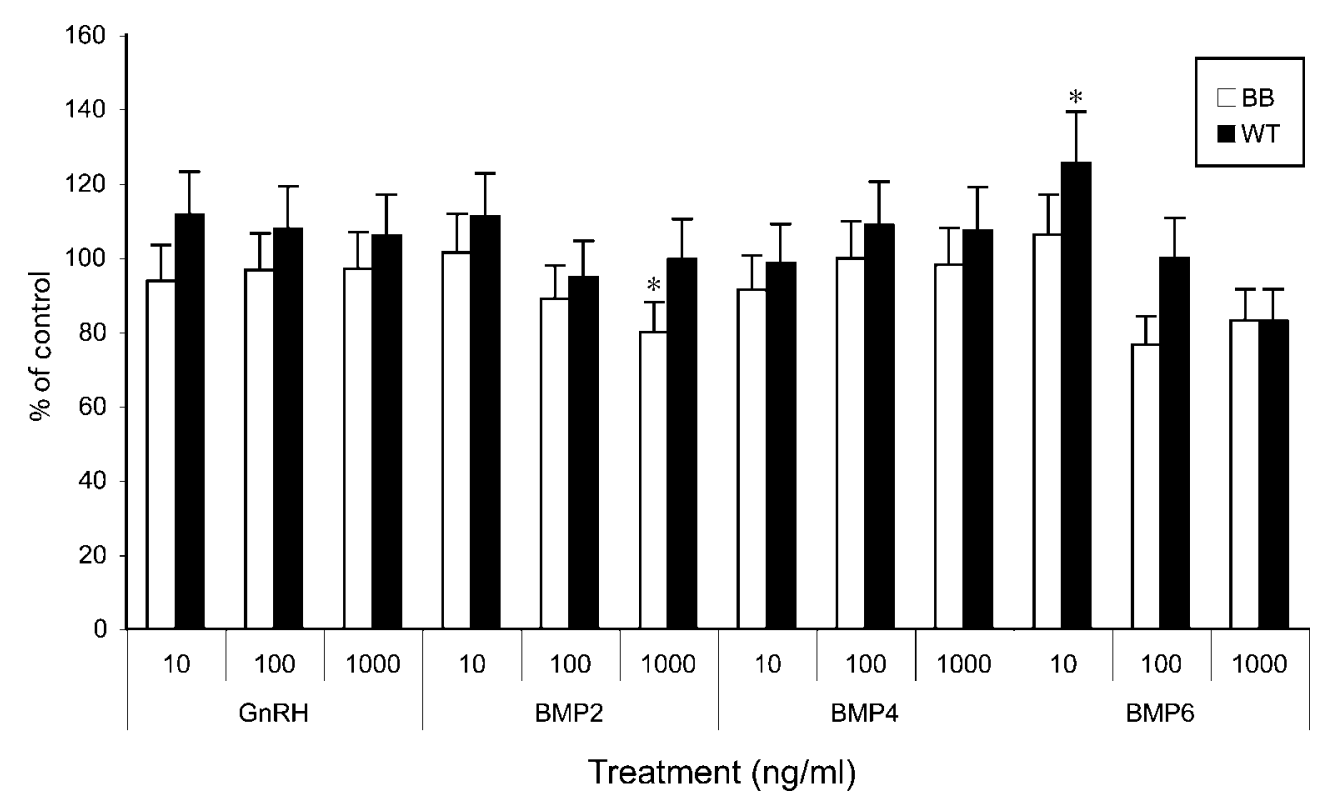

Figure 2 Dose-response of GnRH, BMP2, BMP4 and BMP6 on FSH stored in ewe pituitary cells. Values are the analysed ratios of the treatment when compared with the control for each genotype. The standard errors of the ratio (SERs) over five to six pools of pituitary cells from each genotype range between $10 \cdot 2$ and $10 \cdot 9 \%$ for each treatment. The estimated mean times the SER are indicated by error bars. ${ }^{*} P<0.05$ compared with control.

significant suppression was not observed from WT cells at any of these concentrations.

The concentration of FSH in the cell lysates was measured after treatment with activin-A, TGF $\beta 1$ and GDF9 (Fig. 5). Activin-A increased the concentration of FSH in cell lysates from both the genotypes $(P<0 \cdot 05)$ at 100 and
$P<0 \cdot 001)$ at $1000 \mathrm{ng} / \mathrm{ml}$ for both $\mathrm{BB}$ and WT, $P<0.05$ at $1 \mathrm{ng} / \mathrm{ml}$ in $\mathrm{BB}$, and $P<0.005$ for WT at $10 \mathrm{ng} / \mathrm{ml})$, but there was no significant difference between genotypes. GDF9 appears to have an effect on FSH content in WT cell lysates but not in BB cell lysates with GDF9 stimulating an increased concentration of FSH at low, but not high, doses.

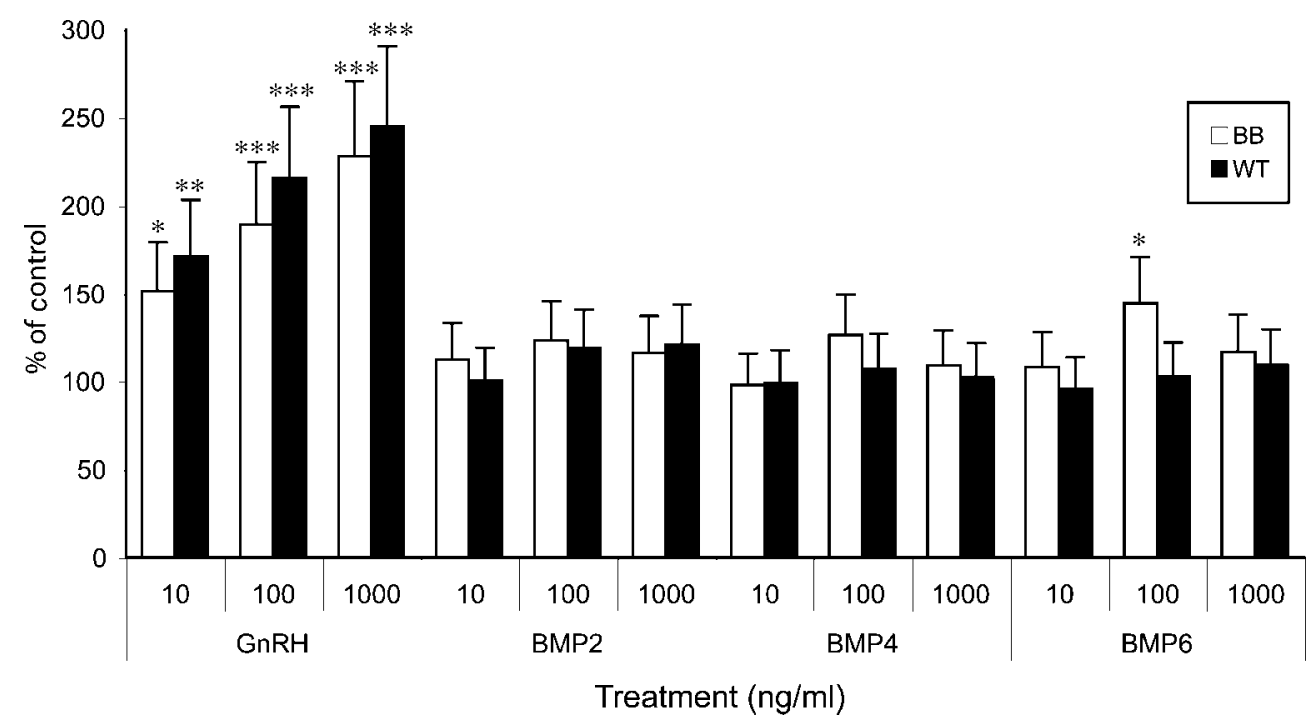

Figure 3 Dose-response of GnRH, BMP2, BMP4 and BMP6 on LH release from ewe pituitary cells. Values are the analysed ratios of the treatment when compared with the control for each genotype. Standard errors of the ratio (SERs) over five to six pools of pituitary cells from each genotype range between 18.3 and $18.6 \%$ for each treatment. The estimated mean times the SER are indicated by error bars. ${ }^{*} P<0 \cdot 05,{ }^{* *} P<0 \cdot 01,{ }^{* * *} P<0 \cdot 001$ compared with control. 


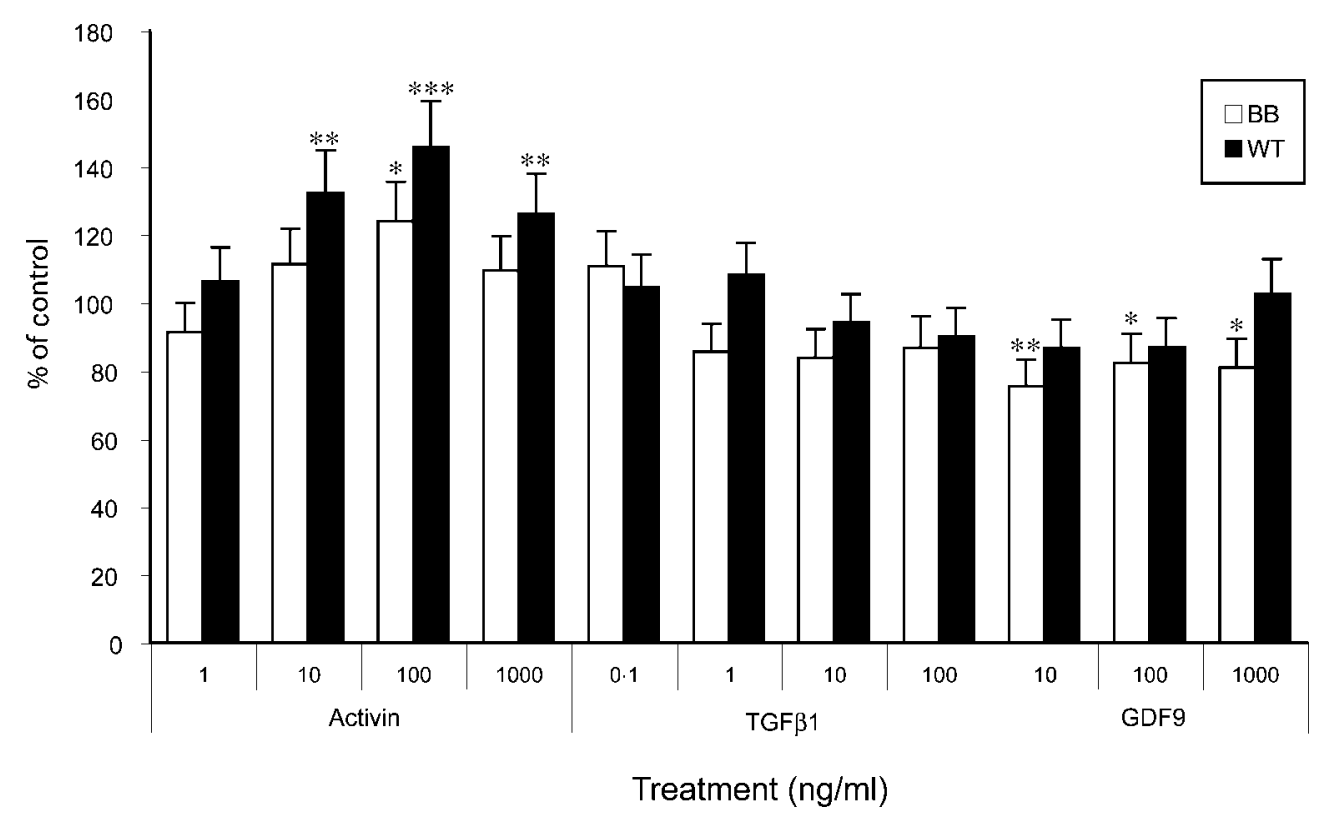

Figure 4 Dose-response of activin-A, TGF $\beta 1$ and GDF9 on FSH release from ewe pituitary cells. Values are the analysed ratios of the treatment when compared with the control for each genotype. Standard errors of the ratio (SERs) over five to six pools of pituitary cells from each genotype range between $8 \cdot 8$ and $10 \cdot 1 \%$ for each treatment. The estimated mean times the SER are indicated by error bars. ${ }^{*} P<0 \cdot 05,{ }^{* *} P<0 \cdot 01,{ }^{* * *} P<0 \cdot 001$ compared with control.

The difference between genotype responses was significant $(P<0 \cdot 05)$ at $10 \mathrm{ng} / \mathrm{ml}$ GDF9.

The concentrations of $\mathrm{LH}$ secreted into the culture media were determined (Fig. 6). When $100 \mathrm{ng} / \mathrm{ml}$ activin was added to $\mathrm{BB}$ cultures, a significant $(P<0 \cdot 01)$ increase in the $\mathrm{LH}$ secretion was observed. However, there were no consistent effects of activin across the doses $(1-1000 \mathrm{ng} / \mathrm{ml})$ tested on the amount of $\mathrm{LH}$ secreted in either BB or WT cultures.

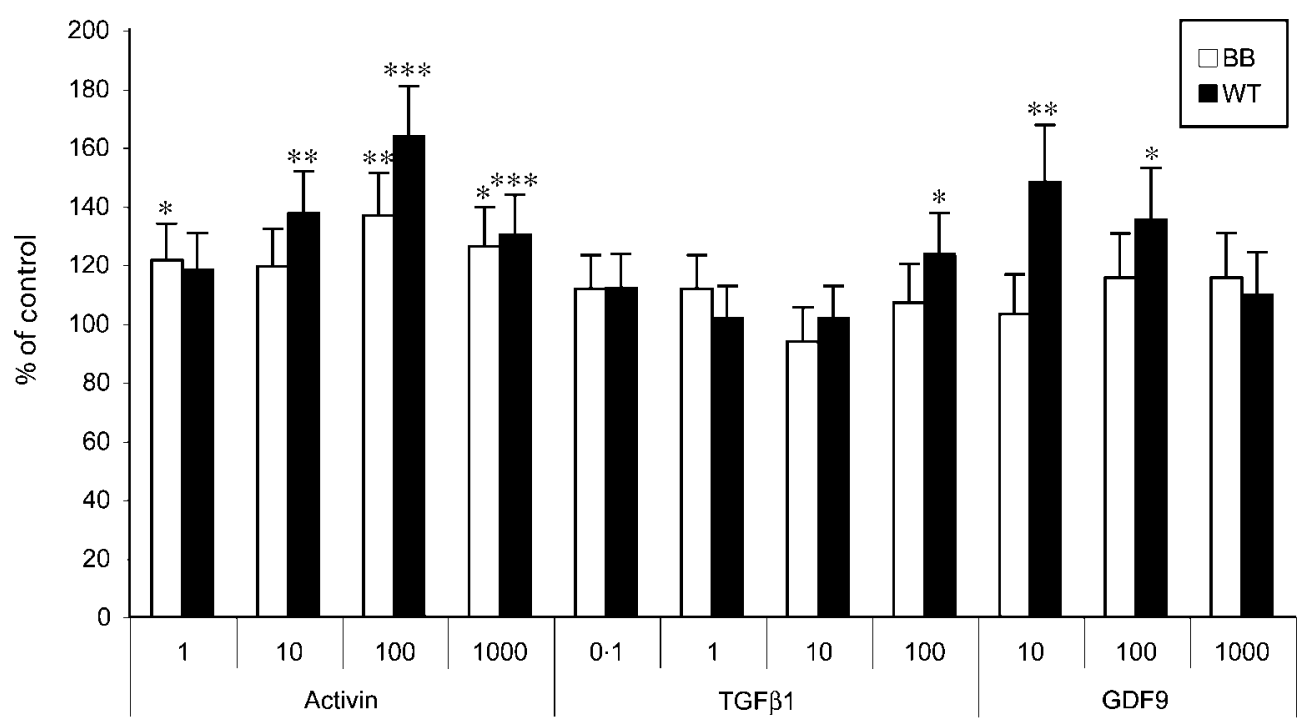

Treatment $(\mathrm{ng} / \mathrm{ml})$

Figure 5 Dose-response of activin-A, TGF $\beta 1$ and GDF9 on FSH stored in ewe pituitary cells. Values are the analysed ratios of the treatment when compared with the control for each genotype. Standard errors of the ratio (SERs) over five to six pools of pituitary cells from each genotype range between $10 \cdot 2$ and $13 \cdot 3 \%$ for each treatment. The estimated mean times the SER are indicated by error bars. ${ }^{*} P<0 \cdot 05,{ }^{* *} P<0 \cdot 01,{ }^{* * *} P<0 \cdot 001$ compared with control. 


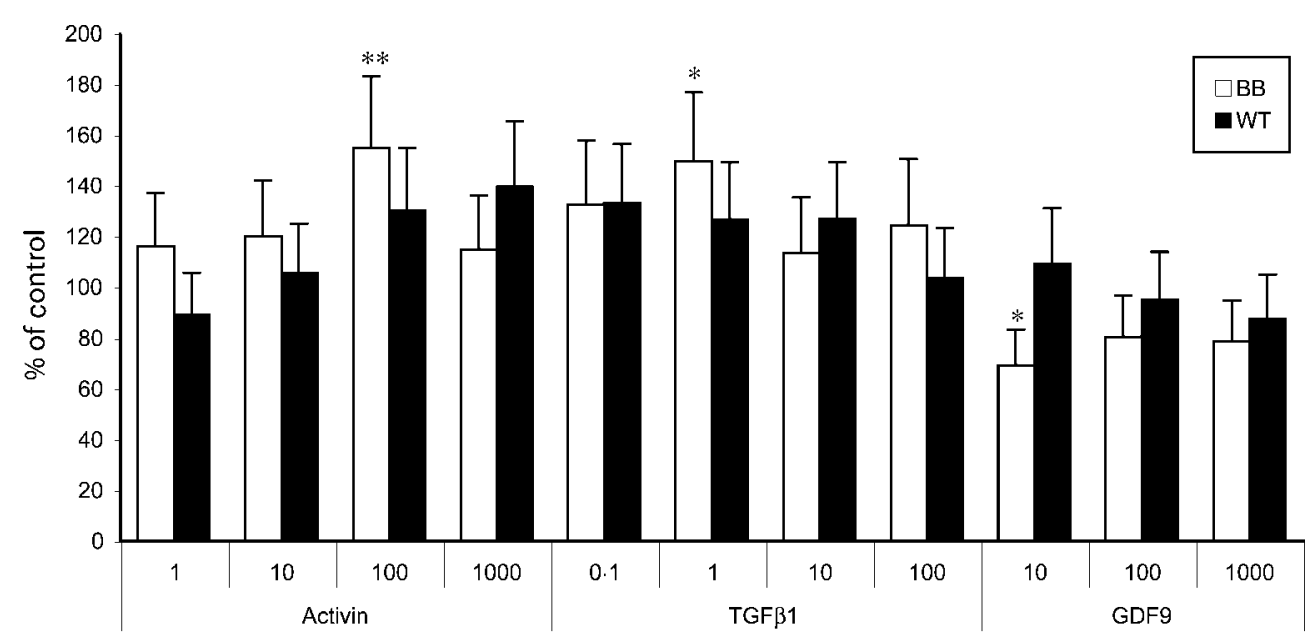

Treatment $(\mathrm{ng} / \mathrm{ml})$

Figure 6 Dose-response of activin-A, TGF $\beta 1$ and GDF9 on LH release from ewe pituitary cells. Values are the analysed ratios of the treatment when compared with the control for each genotype. Standard errors (SERs) of the ratio over five to six pools of pituitary cells from each genotype range between 17.5 and $21.0 \%$ for each treatment. The estimated mean times the SER are indicated by error bars. ${ }^{*} P<0 \cdot 05, * * P<0 \cdot 01$ compared with control.

TGF $\beta 1$ stimulated $\mathrm{LH}$ secretion in $\mathrm{BB}$ cultures at $1 \mathrm{ng} / \mathrm{ml}$ $(P<0 \cdot 05)$; however, significant increases in the LH secretion were not observed at any other concentrations of TGF $\beta 1$. The opposite effect was observed when $10 \mathrm{ng} / \mathrm{ml} \mathrm{GDF9}$ was added to $\mathrm{BB}$ cultures, which inhibited LH secretion $(P<0 \cdot 05)$. This effect was not significant at any other concentrations of GDF9 in either the BB or WT cultures.

\section{ALK6 does not co-localise with gonadotroph cells}

Immunohistochemistry analyses of BB and WT pituitary tissue harvested at follicular or mid-luteal phases of oestrus showed that ALK6 and BMPRII are both present in the pituitary gland (Fig. 7). A comparison of tissues from each genotype detected no differences between the number of cells stained for ALK6, BMPRII, FSH and LH in the luteal or follicular phases, or between the homozygous carrier when compared with non carrier tissues (Table 1).

\section{Discussion}

BMP2, BMP4 and BMP6 suppressed FSH secretion from cultured pituitary cells from BB ewes. The BMPs acted in a similar manner with WT pituitary cells but the level to which FSH was suppressed was often not significant relative to the untreated controls. These findings are consistent with those of Faure et al. (2005) who showed that BMP4 and BMP6 inhibit FSH $\beta$ mRNA production as well as FSH release from ovine pituitary cells. However, neutralisation of BMP7 decreased FSH
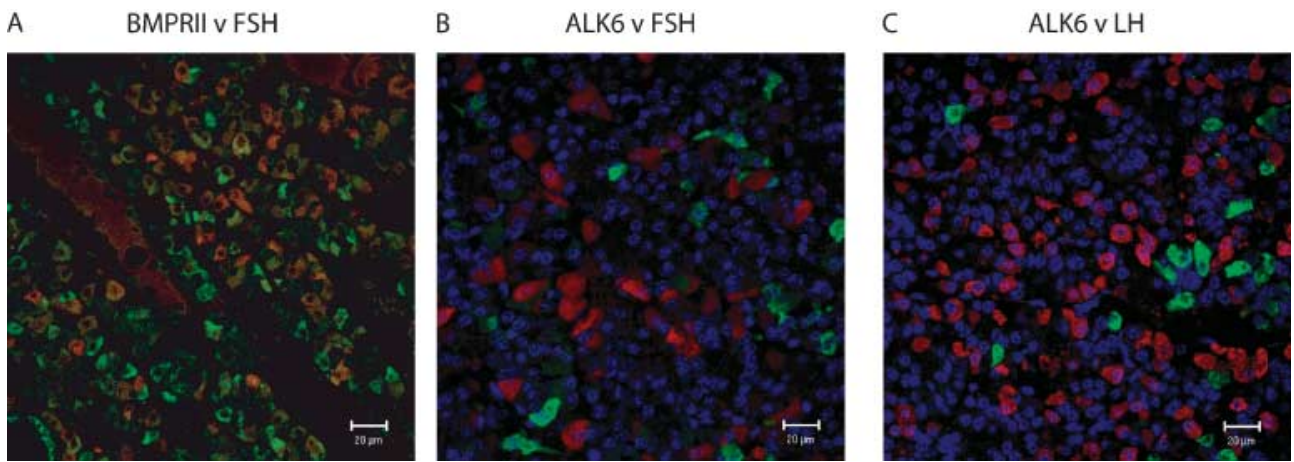

Figure 7 Localisation of ALK6 protein (green) and BMPRII protein (green) with gonadotrophs (red, detected with antibodies against $\mathrm{LH}$ or FSH) in sheep pituitary tissue. Images showing detection of BMPRII and FSH (A), ALK6 and FSH (B), and ALK6 and LH (C). All sections were counterstained with TopRo Blue to locate the nucleus, although strong staining in BMPRII analyses hindered visualisation. 
Table 1 Percentage of cells that stained for gonadotrophin alone, receptor alone or both gonadotrophin and receptor in wild-type (WT) and homozygous Booroola carrier (BB) ewes

(A) Co-localisation of follicle-stimulating hormone (FSH) and bone morphogenetic protein receptor II (BMPRII)

\begin{tabular}{|c|c|c|c|}
\hline & FSF & BMPRII only & $\begin{array}{l}\text { FSH and } \\
\text { BMPRII }\end{array}$ \\
\hline $\begin{array}{l}\text { BB (2180 cells } \\
\text { counted) }\end{array}$ & $0 \cdot 09 \pm 0 \cdot 07 \%$ & $45 \cdot 0 \pm 1 \cdot 0 \%$ & $54 \cdot 9 \pm 1 \cdot 1 \%$ \\
\hline $\begin{array}{l}\text { WT }(2046 \text { cells } \\
\text { counted) }\end{array}$ & 0 & $50 \cdot 6 \pm 1 \cdot 1 \%$ & $49 \cdot 4 \pm 1 \cdot 1 \%$ \\
\hline
\end{tabular}

(B) Co-localisation of FSH and activin receptor-like kinase 6 (ALK6)

\begin{tabular}{|c|c|c|c|}
\hline & FSH only & ALK6 only & FSH and ALK6 \\
\hline $\begin{array}{l}\text { BB }(9748 \text { cells } \\
\text { counted) }\end{array}$ & $69 \cdot 5 \pm 0 \cdot 5 \%$ & $30 \cdot 5 \pm 0 \cdot 5 \%$ & 0 \\
\hline $\begin{array}{l}\text { WT (7991 cells } \\
\text { counted) }\end{array}$ & $65 \cdot 5 \pm 0 \cdot 5 \%$ & $34 \cdot 5 \pm 0 \cdot 5 \%$ & 0 \\
\hline \multicolumn{4}{|c|}{ C) Co-localisation of luteinising hormone (LH) and ALK6 } \\
\hline & $\underline{\text { LH only }}$ & ALK6 only & $\underline{\text { LH and ALK6 }}$ \\
\hline $\begin{array}{l}\text { BB (13 351 } \\
\text { cells counted) }\end{array}$ & $77 \cdot 8 \pm 0 \cdot 4 \%$ & $22 \cdot 2 \pm 0 \cdot 4 \%$ & $0 \cdot 01 \pm 0 \cdot 4 \%$ \\
\hline $\begin{array}{l}\text { WT ( } 12229 \\
\text { cells counted) }\end{array}$ & $76 \cdot 0 \pm 0 \cdot 4 \%$ & $24 \cdot 0 \pm 0 \cdot 4 \%$ & 0 \\
\hline
\end{tabular}

secretion in primary ovine pituitary cells, suggesting a stimulatory role for BMP7 (Huang et al. 2001). Thus, the different BMPs may differentially regulate FSH secretion in this species. BMP6 and BMP7 were shown to stimulate an oFSH $\beta$ Luc reporter construct in a rodent pituitary cell line (L $\beta T 2)$ by fourfold. Furthermore, the addition of BMP6 and BMP7 to LBT2 cell cultures increased endogenous FSH secretion 10-14 fold (Huang et al. 2001). Thus, in rodent pituitary cells, BMP6 and BMP7 appear to function as FSH stimulators. Similarly, BMP15 potently and selectively stimulated FSH, but not LH, secretion in rodent primary pituitary cells (Otsuka \& Shimasaki 2002). These studies confirm that TGF $\beta$ superfamily members are involved in modulating gonadotropin production in several species. However, it appears that the response to BMPs varies amongst species and family members.

GDF9 also inhibited FSH secretion in BB but not in the WT cells. This suggests that GDF9 is acting like a BMP rather than a TGF $\beta$, as TGF $\beta 1$ had no significant effect on FSH secretion in either BB or WT genotypes. GDF9 is expressed in sheep pituitary tissue (Faure et al. 2005) and the present theory is that GDF9 acts through the BMPRII receptor and TGF $\beta$ type I receptors (Alk5) to activate the Smad 3 pathway (Kaivo-Oja et al. 2005). BMP2 and BMP4 both bind to BMPRII and ALK3/6 (BMPRIA/B) activating the Smad 1/5/8 pathway, but BMP6 and BMP7 are thought to bind to BMPRII as well as the activin receptors ActRII/IIB and ALK2 (ActRIA) in addition to ALK6 (see Shimasaki et al. 2004 for a review). Thus, it appears that the effects of the TGF $\beta$ superfamily members are not necessarily consistent when activating either the Smad $1 / 5 / 8$ or the Smad $2 / 3$ pathway as both positive and negative effects of ligands activating these different pathways have been observed in the same species (current study, Huang et al. 2001, Miyazawa et al. 2002, Faure et al. 2005). Moreover, the actions of the other TGF $\beta$ superfamily members such as activin and inhibin have opposing effects on FSH production (see Welt et al. 2002 for review). Given the divergence within the functions of TGF $\beta$ superfamily members, regulation of FSH secretion appears complex and may involve signalling pathways outside of the Smad signalling molecules.

Concentrations of intracellular FSH were similar in BB and WT cells in the presence of all ligands tested, with the exception of GDF9. Activin-A increased the concentrations of FSH in the cell lysates showing that a functional FSH intracellular storage system exists. A similar increase in intracellular FSH concentrations was observed when WT pituitary cells were treated with GDF9; however, no such effect was observed in the BB pituitary cells. This apparent dichotomy may explain the suppression observed in the concentrations of FSH secreted from BB but not WT pituitary cells treated with GDF9 and suggests the possibility of different regulatory mechanisms controlling the synthesis and release of FSH by TGF $\beta$ superfamily members. The BMPs did not affect the storage of FSH in pituitary cell cultures from either genotype. Thus, the presence of the ALK6 Booroola mutation did not affect the amount of FSH being stored within the cells, but only the amount being secreted in response to BMP2, BMP4 and BMP6. Given that the BMPs decreased the FSH secretion without a change in the intracellular concentration of $\mathrm{FSH}$, it seems likely that the total amount of FSH produced by the cells was reduced by treatment with BMPs. This is in agreement with the observed suppressive effect of BMPs on FSH $\beta$ mRNA concentrations and decreased levels of FSH secreted from ovine pituitary cultures (Faure et al. 2005).

GnRH stimulated LH release in pituitary cells from both genotypes. None of the BMPs, activin, GDF9 or TGF $\beta 1$ had any consistent effect on the level of LH secreted when compared with the untreated controls. These results show that the cells are capable of responding to ligands, but that only $\mathrm{GnRH}$ causes a change in the amount of $\mathrm{LH}$ secreted. There was no evidence that the BB cells containing the ALK6 mutation produced differing amounts of $\mathrm{LH}$ in response to any of the treatments. This result is not surprising given that activin and inhibin are well-established regulators of FSH, independent of $\mathrm{LH}$ (reviewed in (Welt et al. 2002)). Furthermore, recent research indicates that other members of the TGF $\beta$ superfamily also appear to consistently regulate FSH secretion independent of LH (Otsuka \& Shimasaki 2002, Faure et al. 2005).

When the data are analysed across all concentrations of BMP2, BMP4 and BMP6, there is a general trend towards a significant genotype effect in FSH production. The genotype effect indicates that the BMP ligands have a greater inhibitory influence on FSH secretion in pituitary cells from $\mathrm{BB}$ when compared with WTanimals over a 24 -h culture period. This is likely to be due to the genetic background of the ewes as this was the only known variable between cultures from each genotype BB or WT. 
The effect of the ALK6 Booroola mutation on its function as a receptor in the BMP cascade is not clear. When analysing the effect of the mutation on activation of the Smad signalling pathway, an increased basal activity was noted along with a failure to respond to BMP ligands (Fabre et al. 2003). If the overriding effect was an increased basal activity, we would expect that FSH levels would be lower in BB cells than WT cells in an untreated state given that the addition of BMPs to pituitary cell cultures appear to inhibit FSH secretion. However, this was not the case either in vitro or in vivo. If the mutation caused partial inactivation of the receptor we would predict that BMPs would function less efficiently on BB cells when compared with WT. However, this was not observed in the present study. Collectively, it appears that regulation of FSH by members of the TGF $\beta$ superfamily is complex and likely represents an integration of both positive and negative signals interacting in multiple pathways.

In the present study, BMPs suppressed FSH secretion to a greater extent in $\mathrm{BB}$ cells than in WT cells. In a previous study (Faure et al. 2005), FSH secretion was measured from ovine pituitary cells over $72 \mathrm{~h}$ of culture. As time increased, the effects of BMP treatment on suppressing secretion of FSH in WTovine cultures was more pronounced. At $24 \mathrm{~h}$, the difference between BMP4-treated and the control was much smaller than that observed after $72 \mathrm{~h}$ in culture. Thus, the failure of the BMPs to induce a statistically significant suppression of FSH in WT cells in the present study is perhaps related to the shorter culture period. The observed suppression of FSH in the BB cultures after $24 \mathrm{~h}$ of treatment would indicate that the BB cells were likely more sensitive to BMPs than WT cells.

For the ALK6 receptor mutation to have a direct effect on gonadotroph cell function, it would need to be expressed in gonadotroph cells themselves. In a study carried out on pituitaries from the New Zealand Booroola flock, no differences between $\mathrm{BB}$ and $\mathrm{WT}$ pituitary tissues in the total number of pituitary cells, pituitary volume or diameter, or the numbers of FSH- or LH-containing cells were observed (Heath et al. 1996). Immunohistochemical studies did not show the presence of ALK6 on gonadotroph cells of pituitary tissue from sheep not carrying the ALK6 Booroola mutation (Faure et al. 2005). This result was confirmed in our study. Moreover, no differences were observed between BB and WT pituitary tissue during either the follicular or the mid-luteal phase of the oestrous cycle. Taken together, this would indicate that the genotype effect observed cannot be due to the direct action of the mutant Booroola ALK6 receptor in the cells synthesising FSH, but that the sensitivity of BB cells to BMPs appears enhanced when compared with WT cells. BMPs may potentially act through the type IA BMP receptor (ALK3), which has been shown to be expressed in ovine gonadotroph cells (Faure et al. 2005). Differential expression of this receptor between BB and WT sheep potentially could be involved in the observed increased sensitivity to BMPs observed in BB pituitary cells.

The physiological mechanisms underlying the increased concentrations of FSH observed in vivo in New Zealand BB ewes remain unclear. However, given that gonadotrophs do not contain ALK6 and pituitary cells from BB ewes were more sensitive to the suppressive effects of BMPs then WT ewes, it seems difficult to see how the mutation in ALK6 would increase the FSH concentrations in the New Zealand Booroola flock. Potentially, the mutation in ALK6 might alter the interactions of BMPs with other factors regulating FSH secretion in vivo that were not duplicated in vitro. One such factor might be GnRH; however, to our knowledge, little is known regarding the interaction of GnRH and BMPs and thus how these interactions might regulate $\mathrm{FSH}$ secretion in vivo is unknown.

As mentioned earlier, it remains uncertain whether the higher FSH concentrations are specifically related to the Booroola mutation or are the consequence of another genetic effect, which was co-inherited when Booroola carrier ewes were selected on the basis of the high ovulation rates before genetic markers were available. This interpretation is based on the reports which show that Booroola sheep have not always showed consistent differences in plasma FSH concentrations or in pituitary FSH secretion (Driancourt et al. 1991, McNatty et al. 1991a,b, Souza et al. 1997, Montgomery et al. 2001, Campbell et al. 2003). Additionally, the possibility of a second mutation being present in the New Zealand Booroola flock has been raised (Farquhar et al. 2006). In this report, the ovulation rates show increases of $0 \cdot 15$ ovulations per year in the homozygous mutant Booroola animals when compared with 0.04 per year in high-prolificacy Romney, Coopworth and Perendale flocks selected solely on ovulation rate. Thus, the differing effects of members of the TGF $\beta$ superfamily on FSH secretion in BB pituitary cells and/or the increased concentrations of FSH in vivo could potentially be unrelated to the mutation in ALK6.

In conclusion, under in vitro conditions no differences were noted between $\mathrm{BB}$ and WT pituitary cells in their ability to stimulate FSH secretion in response to $\mathrm{GnRH}, \mathrm{BMP} 2$, BMP4, BMP6 and GDF9, but not TGF $\beta 1$; all tended to suppress FSH release from ovine pituitary cells in vitro. BMPs were without effect on LH secretion or FSH storage. The inhibitory effect of BMPs and GDF9 on FSH secretion was significantly greater in pituitary cells harvested from homozygous carriers of the ALK6 mutation when compared with non-carrier animals.

\section{Acknowledgements}

We would like to thank NIDDK for FSH and LH RIA reagents, and acknowledge Phil Farqhar, Gordon Greer, Anne O'Connell, Sara Edwards, Evelyn Bauer, Laurel Quirke and Peter Smith for all their technical help with the animals and in the slaughterhouse. We also thank Tim Manley and Ian Ross for their advice and guidance through RIA work. This work was supported by Ovita, FRST (Foundation for Research, Science and Technology), AgResearch, by a University of Otago Postgraduate Scholarship, Education NZ Study Abroad Scholarship and an Elman Poole Travelling Fellowship. The 
authors declare that there is no conflict of interest that would prejudice the impartiality of this scientific work.

\section{References}

Campbell BK, Baird DT, Souza CJ \& Webb R 2003 The FecB (Booroola) gene acts at the ovary: in vivo evidence. Reproduction 126 101-111.

Carroll RS, Corrigan AZ, Vale W \& Chin WW 1991a Activin stabilizes follicle-stimulating hormone-beta messenger ribonucleic acid levels. Endocrinology 129 1721-1726.

Carroll RS, Kowash PM, Lofgren JA, Schwall RH \& Chin WW 1991 b In vivo regulation of FSH synthesis by inhibin and activin. Endocrinology 129 3299-3304.

Chard 1995 An introduction to radioimmunoassay and related techniques.

Davis GH 2004 Fecundity genes in sheep. Animal Reproduction Science 82-83 $247-253$.

Driancourt MA, Bodin L \& Fry CR 1991 FSH secretion, its regulation and its relationship with ovulation rate in a range of prolific and non prolific breeds of sheep. Major Genes for Reproduction in Sheep, ch 8, pp 125-134.

Fabre S, Pierre A, Pisselet C, Mulsant P, Lecerf F, Pohl J, Monget P \& Monniaux D 2003 The Booroola mutation in sheep is associated with an alteration of the bone morphogenetic protein receptor-IB functionality. Journal of Endocrinology 177 435-444.

Farquhar PA, Dodds KG \& Davis GH 2006 Introgression of the Booroola mutation (FECB) leads to hyper-prolificacy in a Romney sheep flock. Proceedings of 8 th World Congress on Genetics Applied to Livestock Production, Belo Horizonte.

Faure MO, Nicol L, Fabre S, Fontaine J, Mohoric N, McNeilly A \& Taragnat C 2005 BMP-4 inhibits follicle-stimulating hormone secretion in ewe pituitary. Journal of Endocrinology 186 109-121.

Heath DA, Caldani M \& McNatty KP 1996 Relationship between the number of immunostaining gonadotropes and the plasma concentrations of gonadotrophins in ewes with and without the FecBB gene. Journal of Reproduction and Fertility 106 73-78.

Huang HJ, Wu JC, Su P, Zhirnov O \& Miller WL 2001 A novel role for bone morphogenetic proteins in the synthesis of follicle-stimulating hormone. Endocrinology 142 2275-2283.

Hudson NL, O'Connell AR, Shaw L, Clarke IJ \& McNatty KP 1999 Effect of exogenous FSH on ovulation rate in homozygous carriers or noncarriers of the Booroola FecB gene after hypothalamic-pituitary disconnection or after treatment with a GnRH agonist. Domestic Animal Endocrinology 16 69-80.

Kaivo-Oja N, Mottershead DG, Mazerbourg S, Myllymaa S, Duprat S, Gilchrist RB, Groome NP, Hsueh AJ \& Ritvos O 2005 Adenoviral gene transfer allows Smad-responsive gene promoter analyses and delineation of type I receptor usage of transforming growth factor-beta family ligands in cultured human granulosa luteal cells. Journal of Clinical Endocrinology and Metabolism 90 271-278.

McLeod BJ, Fenton LF, Davis GH, Bruce GD, Manley TR \& Johnstone PD 1997 Identifying infertile homozygous Inverdale (FecXI) ewe lambs on the basis of genotype differences in reproductive hormone concentrations. Animal Reproduction Science 47 291-302.

McNatty KP, Hudson N, Henderson KM, Gibb M, Morrison L, Ball K \& Smith P 1987 Differences in gonadotrophin concentrations and pituitary responsiveness to $\mathrm{GnRH}$ between Booroola ewes which were homozygous $(\mathrm{FF})$, heterozygous $(\mathrm{F}+)$ and non-carriers $(++)$ of a major gene influencing their ovulation rate. Journal of Reproduction and Fertility $80577-588$.

McNatty KP, Fisher M, Collins F, Hudson NL, Heath DA, Ball K \& Henderson KM 1989 Differences in the plasma concentrations of FSH and LH in ovariectomized Booroola FF and ++ ewes. Journal of Reproduction and Fertility 85 705-713.

McNatty KP, Hudson NL, Shaw L, Condell LA, Ball K, Seah SL \& Clarke IJ 1991a GnRH-induced gonadotrophin secretion in ovariectomized Booroola ewes with hypothalamic-pituitary disconnection. Journal of Reproduction and Fertility 91 583-592.

McNatty KP, Henderson KM, Fleming JS, Clarke IJ, Bindon BM, Piper LR, O'Shea T, Hillard MA \& Findlay JK $1991 b$ The Physiology of the Booroola Ewe. Major Genes for Reproduction in Sheep, ch 7, pp 105-124.
McNatty KP, Heath DA, Hudson NL, Ball K \& Condell L 1992 Concentrations of immunoreactive inhibin in ovarian and peripheral venous plasma and follicular fluid of Booroola ewes that are homozygous carriers or non-carriers of the FecB gene. Journal of Reproduction and Fertility 95 489-502.

McNatty KP, Hudson NL, Lun S, Heath DA, Shaw L, Condell L, Phillips DJ \& Clarke IJ 1993 Gonadotrophin-releasing hormone and the control of ovulation rate by the FecB gene in Booroola ewes. Journal of Reproduction and Fertility 98 97-105.

McNatty KP, Juengel JL, Reader KL, Lun S, Myllymaa S, Lawrence SB, Western A, Meerasahib MF, Mottershead DG, Groome NP et al. 2005 Bone morphogenetic protein 15 and growth differentiation factor 9 co-operate to regulate granulosa cell function. Reproduction 129 473-480.

Miyazawa K, Shinozaki M, Hara T, Furuya T \& Miyazono K 2002 Two major Smad pathways in TGF-beta superfamily signalling. Genes to Cells 7 1191-1204

Montgomery GW, Penty JM, Sise JA \& Tou HM 1992 Genes encoding the alpha and beta chains of follicle-stimulating hormone are not sites for the Booroola (FecB) mutation in sheep. Journal of Reproduction and Fertility 95 895-901.

Montgomery GW, Galloway SM, Davis GH \& McNatty KP 2001 Genes controlling ovulation rate in sheep. Reproduction 121 843-852.

Mulsant P, Lecerf F, Fabre S, Schibler L, Monget P, Lanneluc I, Pisselet C, Riquet J, Monniaux D, Callebaut I et al. 2001 Mutation in bone morphogenetic protein receptor-IB is associated with increased ovulation rate in Booroola Merino ewes. PNAS 98 5104-5109.

Otsuka F \& Shimasaki S 2002 A novel function of bone morphogenetic protein-15 in the pituitary: selective synthesis and secretion of FSH by gonadotropes. Endocrinology 143 4938-4941.

Patterson HD \& Thompson R 1971 Recovery of inter-block information when block sizes are unequal. Biometrika 58 545-554.

Shimasaki S, Moore RK, Otsuka F \& Erickson GF 2004 The bone morphogenetic protein system in mammalian reproduction. Endocrine Reviews 25 72-101.

Souza CJ, Campbell BK, Webb R \& Baird DT 1997 Secretion of inhibin A and follicular dynamics throughout the estrous cycle in the sheep with and without the Booroola gene (FecB). Endocrinology 138 5333-5340.

Souza CJ, MacDougall C, Campbell BK, McNeilly AS \& Baird DT 2001 The Booroola $(\mathrm{FecB})$ phenotype is associated with a mutation in the bone morphogenetic receptor type 1 B (BMPR1B) gene. Journal of Endocrinology 169 R1-R6.

Souza CJ, Campbell BK, McNeilly AS \& Baird DT 2002 Effect of bone morphogenetic protein 2 (BMP2) on oestradiol and inhibin A production by sheep granulosa cells, and localization of BMP receptors in the ovary by immunohistochemistry. Reproduction 123 363-369.

Weiss J, Harris PE, Halvorson LM, Crowley WF, Jr \& Jameson JL 1992 Dynamic regulation of follicle-stimulating hormone-beta messenger ribonucleic acid levels by activin and gonadotropin-releasing hormone in perifused rat pituitary cells. Endocrinology 131 1403-1408.

Weiss J, Guendner MJ, Halvorson LM \& Jameson JL 1995 Transcriptional activation of the follicle-stimulating hormone beta-subunit gene by activin. Endocrinology 136 1885-1891.

Welt C, Sidis Y, Keutmann H \& Schneyer A 2002 Activins, inhibins, and follistatins: from endocrinology to signalling. A paradigm for the new millennium. Experimental Biology and Medicine 227 724-752.

Wilson T, Wu XY, Juengel JL, Ross IK, Lumsden JM, Lord EA, Dodds KG, Walling GA, McEwan JC, O'Connell AR et al. 2001 Highly prolific Booroola sheep have a mutation in the intracellular kinase domain of bone morphogenetic protein IB receptor (ALK-6) that is expressed in both oocytes and granulosa cells. Biology of Reproduction $641225-1235$.

Received in final form 18 October 2007

Accepted 5 November 2007

Made available online as an Accepted Preprint 5 November 2007 